Вісник Харківського національного університету імені В.Н. Каразіна Серія "Математика, прикладна математика і механіка"

Том 91,2020 , с. $36-44$

УДК 519.6
Visnyk of V.N.Karazin Kharkiv National University Ser. "Mathematics, Applied Mathematics and Mechanics"

Vol. 91, 2020, p. 36-44

DOI: $10.26565 / 2221-5646-2020-91-03$

\title{
Different strategies in the liver regeneration processes. Numerical experiments on the mathematical model
}

\author{
V. V. Karieva ${ }^{1}$, S. V. Lvov ${ }^{1}$, L. P. Artyukhova ${ }^{2}$ \\ ${ }^{1}$ V. N. Karazin Kharkiv National University \\ Svobody sqr., 4, 61022, Kharkiv, Ukraine \\ ${ }^{2}$ Kharkiv college of State University of Telecommunications \\ str. Kooperativna, 7, 61003, Kharkiv, Ukraine \\ valerija.kareva@gmail.com,lvovser@gmail.com,lp.artyukhova@gmail.com
}

It is considered the mathematical model which describes the processes of liver regeneration with homogeneous approximation. Numerical calculations revealed that the mathematical model corresponds to biological processes for different strategies of liver regeneration. Based on the calculations in the case of partial hapatectomy it is concluded that the mixed strategy of regeneration should be used for regeneration process.

Keywords: mathematical model; liver regeneration; numerical experiment.

Карєва В. В., Львов С. В., Артюхова Л. П. Різні стратегії в процесах регенерації печінки. Чисельні експерименти на математичній моделі. У роботі розглянуто математична модель, яка описує процеси регенерації печінки в однорідному наближенні. Показано, що дана модель при різних стратегіях регенерації печінки відповідає біологічним процесам. На основі виконаних обчислень у випадку часткової гапатектомії зроблено висновок, що при регенерації печінки повинна використовуватися змішана стратегія регенерації.

Ключові слова: математична модель; регенерація печінки; чисельний експеримент.

Карева В. В., Львов С. В., Артюхова Л. П. Различные стратегии в процессах регенерации печени. Численные эксперименты на математической модели. В работе рассмотрена математическая модель, описывающая процессы регенерации печени в однородном приближении. Показано, что данная математическая модель при различных стратегиях регенерации печени соответствует биологическим процессам. Проделанные вычисления в случае частичной гапатэктомии демонстрируют, что при регенерации печени должна использоваться смешанная стратегия регенерации.

Ключевые слова: математическая модель; регенерация печени; численный эксперимент.

2010 Mathematics Subject Classification: 92C37, 65Y99.

(C) V. V. Karieva, S. V.Lvov, L. P. Artyukhova, 2020 


\section{Introduction}

In biology and medicine mathematical methods and models are emerging as one of the main tools for obtaining new data on biological systems, their analysis and explanation of the phenomena observed in the experiment. In some cases mathematical methods and models make it possible to find new functions and new phenomena in biological systems as well as to predict their behavior.

Liver regeneration is one of the most captivating phenomena in medicine that has fascinated clinicians, surgeons, and scientists who have observed this apparently supernatural process and studied its mechanisms for many years. The liver is a large, meaty organ and possesses multiple substantial functions in the human body. The identification of the main dependencies and relationships that determine the strategy of liver regeneration is one of the main problems in the regenerative medicine. One way to solve this problem is to develop adequate mathematical models that describe the processes of liver regeneration $[1,2,3]$.

The article deals with the mathematical model that qualitatively describes the processes of liver regeneration in explicit dependence on the control parameters [4]. Developed "toy model"represents the processes of replication, polyploidization and the formation of binuclear cells, hyperplasia, and effects of toxic factors, apoptosis, cell death and the effects of secondary toxicity, the protective reaction of cells and process of detoxification for cells of a generalized parenchymal type. Numerical calculations confirm that the mathematical model corresponds to biological processes for different strategies of liver regeneration.

\section{Review of mathematical model}

There are two events in which the liver has the capability to regenerate, one being a partial hepatectomy and the other being damage to the liver by toxins or infection [10]. Earlier, we have developed a "toy model"of controlled liver regeneration processes in the homogeneous approximation under conditions of mild toxicity or partial hepatectomy [4].

The model is a system of discrete controlled equations of the Lotka Volterra type with transitions. These equations describe the controlled competitive dynamics of liver cell populations' (hepatic lobules) various types in their various states and controlled competitive transitions between types and states.

The liver regeneration occurs due to hyperplasia, replication, polyplodia processes and division of binuclear hepatocytes into mononuclear.

Let us consider:

1) The dynamics of populations of liver cells is given by the equation:

$$
\bar{x}(t+1)=f(\bar{x}(t), \tau(t), \bar{\lambda}(t)),
$$

$$
\operatorname{Tox}(t)=D P(t)+\tau(t)
$$


where $\bar{x}(t)$ - types of functional liver cells at moment $t, \tau(t)$ - given function of external toxicity, $\bar{\lambda}(t)$ - control parameters, $D P(t)$ - internal toxicity due to the toxicity of the decay products as a result of necrosis.

The generalized liver function index is $\Phi(t)=\sum_{i=0}^{m} c_{i}\left(x_{i}(t), \tau(t)\right)$, where $c_{i}$ own index of functionality for cell type $x_{i}(t)$. $0 \leq \Phi(t) \leq 1$, where 0 denotes a dead organism and 1 is the most functional organism.

2) The change of the organism's functional state is described by the equation:

$$
\widetilde{\Phi}(t+1)=\Psi(\tau(t), \Phi(t)) .
$$

As the main functional cells we consider only various types of hepatocytes. The functionality of the liver increases with replication, binuclear division, hyperplasia and under the influence of toxic factors it falls.

In the proposed model the liver structure is described by the following parameters: normal hepatocytes; diploid hepatocytes; tetraploid hepatocytes; binuclear hepatocytes; hepatocytes in a state of hyperplasia, apoptosis and necrosis. Toxic factors are also given: the external toxicity and the secondary toxicity due to decay products of necrosis.

The dynamics of the system is determined by the following control parameters: $a(t)$ - the number of hepatocytes which proceed to the replication; $b(t)$ - the number of hepatocytes which proceed to polyploidy; $b_{2 j}(t)$ - the number of hepatocytes which are initiated into binuclear cells; $a_{2 j}(t)$ - the number of hepatocytes which pass from binuclear hepatocytes per division; $g(t)$ - the number of hepatocytes which proceed to hyperplasia; $\omega(t)$ - the number of hepatocytes which proceed to controlled apoptosis.

A distinctive feature of this model is that in controlled competitive dynamics it explicitly takes into account significantly different characteristic times of the key processes depending on the current level of toxicity. For example, the replication time is 24-36 hours, the transition to polyploidy - 12-18 hours, hyperplasia - 6-8 hours, the division of binuclear hepatocytes - 1-2 hours. The toxic factors can significantly increase process times.

\section{Numerical results and discussion}

The liver has the capability to regenerate after a toxic injury. The pharmacological model is easier to be executed with a greater clinical relevance as it induces a necrotic injury that simulates certain liver diseases. These properties made this model an acceptable option to study liver regeneration. However, raising the toxin concentration can induce acute liver injury while repeated administration of the toxin can lead to liver cirrhosis. Moreover, the systemic and local effects of the toxin depend on doses, animal species, etc [5, 6].

In the proposed mathematical model the process of liver regeneration occurs due to replication process, hyperplasia, polyplodia, division of binuclear cells and controlled apoptosis. All these processes are necessary for adequate modeling of liver regeneration. 
For example, single and constant toxic functions show that the above processes are not able to cope with the toxic factors that are accumulated in the body. The process of the body's functional state restoring requires the non-trivial strategy of liver regeneration.

Firstly consider the replication process of hepatocytes for such cases:

(A) $\operatorname{Tox}(0)=$ Const, $\operatorname{Tox}(t)=0, t=1,2, \ldots$

(B) $\operatorname{Tox}(t)=$ Const, $t=0,1,2, \ldots$
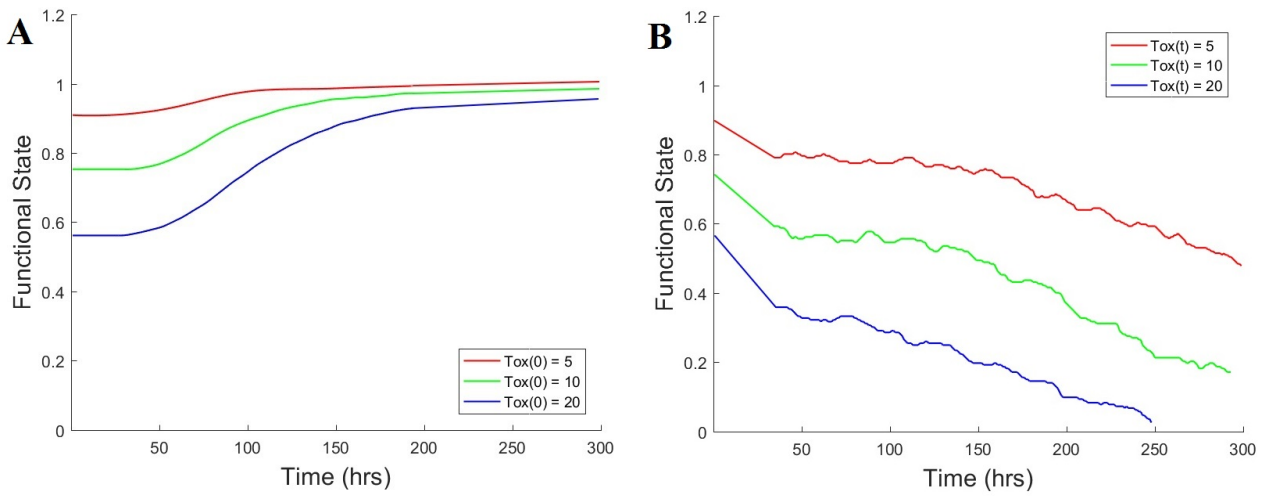

Fig. 1. The body's functionality restoring due to the replication process in the case of single (A) and constant (B) toxic functions.

As shown in Figure 1.A, the time of the body's functionality restoring due to the replication of liver cells is between 32 and 48 hrs. In Figure 1.B it is shown that the body's functionality is gradually reduced due to toxic factors. Note that after 30-40 hours the body's functionality slows down when hepatocytes end the replication cycle. However, as illustrated in Figure 1.B, the replication of liver cells is not able to cope with the growing effect of toxins. In addition to external toxic factors, the decay products of necrosis also have a negative effect on liver cells.

Figures 2.A and 2.B display how the hyperplasia process copes with single and constant toxic functions. Since hyperplasia lasts about 1 hour, the functionality restoring in case (A) occurs almost instantly. But Figure 2.B shows that the hyperplasia process does not cope with prolonged toxicity. It is based on the fact that the cell is unable to grow indefinitely. Therefore, after the liver cells have exhausted their growth resource, it will begin to die gradually. 

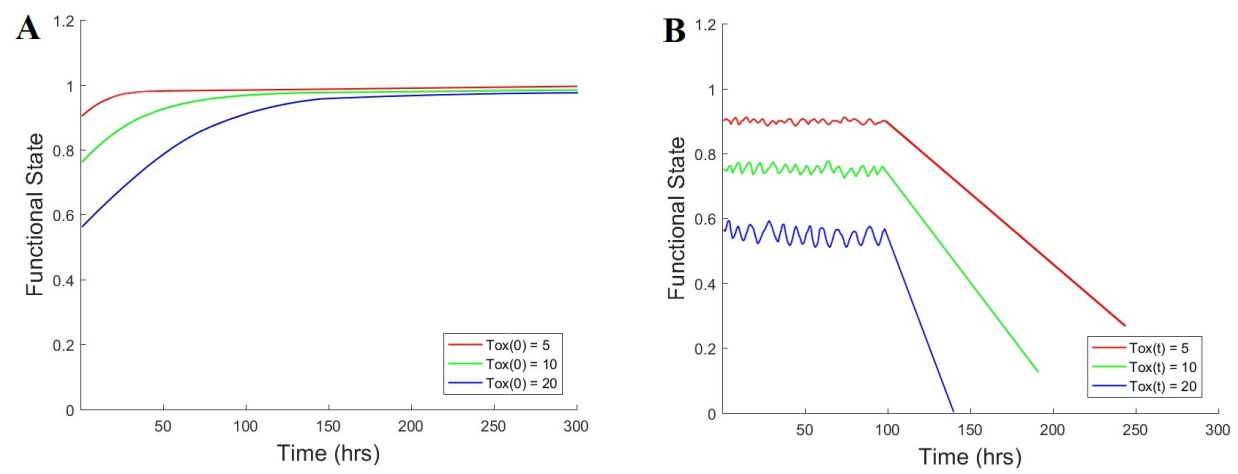

Fig. 2. The body's functionality restoring due to the hyperplasia process in the case of single (A) and constant (B) toxic functions.

Next consider the liver regeneration process due to the division of binuclear cells. Figure 3.A shows that after 6-10 hours the body's functionality is restoring. However the number of binuclear cells in the liver is limited; once all the binuclear cells have separated, the liver will not be able to regenerate. Thus, the liver is destroyed by toxins.
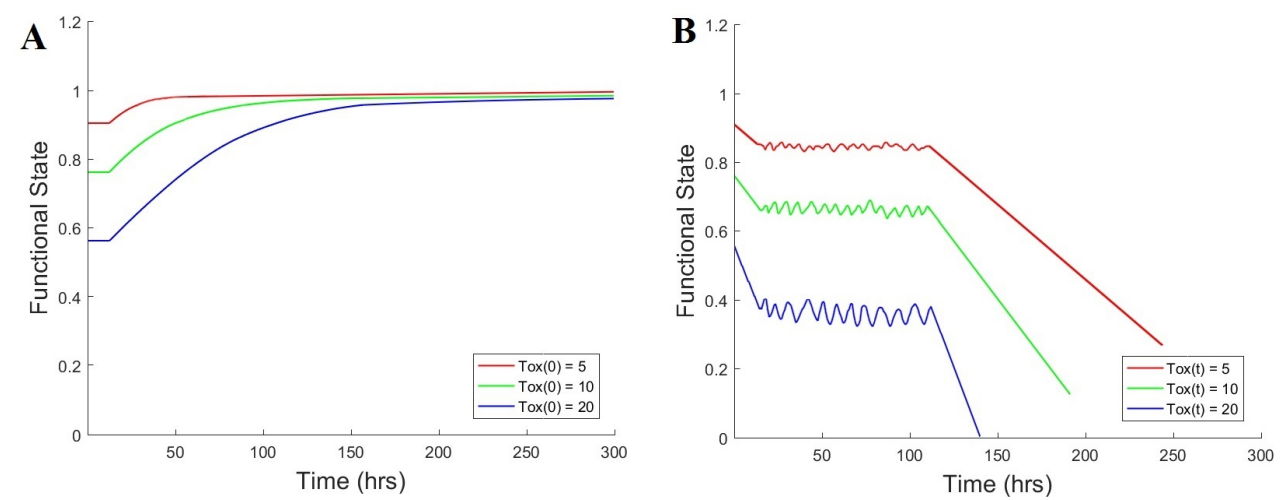

Fig. 3. The body's functionality restoring due to the division of binuclear cells in the case of single (A) and constant (B) toxic functions.

The polyplodia process is similar to the replication process. So that conclusions can be made similar. The functionality restoring due to the polyplodia process is in Figures 4.A and 4.B.

Thus, it is shown that the process of liver regeneration is a complex component process. 

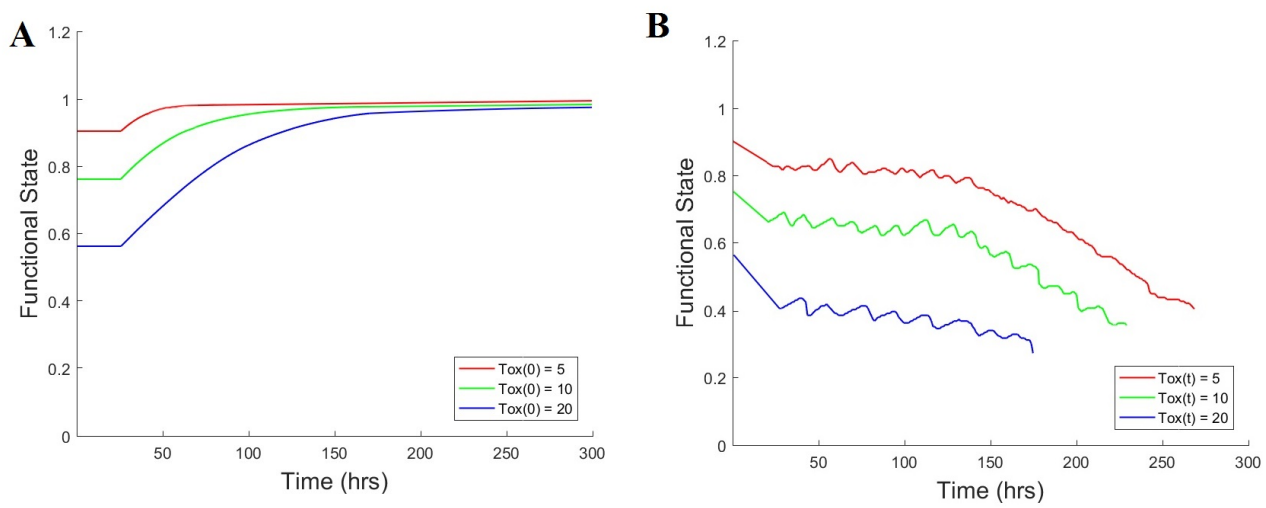

Fig. 4. The body's functionality restoring due to the polyplodia process in the case of single (A) and constant (B) toxic functions.

Induction of liver regeneration by two-third hepatectomy is the most common experimental rodent model used to study this outstanding phenomenon [7]. In order to build a mathematical model for regulation of the regenerating liver after partial hepatectomy, some basic specifications and abstractions of the biological scenario are required.

Following resection, the remaining hepatic tissue proliferates and expands in size to retain the original mass of five lobes within 5-7 days. The peak proliferation time is after $24 \mathrm{hrs}$ in rat whereas, in mice, it is between 36 and $48 \mathrm{hrs}$ [9, 11]. The latter study indicates that liver growth is driven by lobule growth rather than by change of lobule number [8]. At a later remodeling phase liver lobes reorganize into lobules of normal size via restructuring [12].

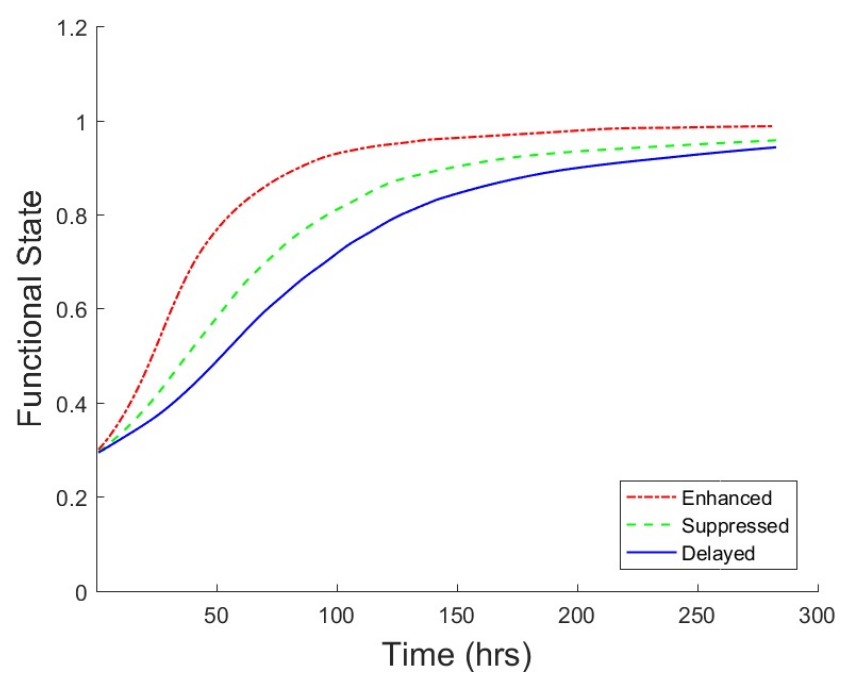

Fig. 5. The body's functionality restoring after partial hepatectomy. 
We simulated the liver regeneration following $70 \%$ hepatectomy. We modeled three regenerating modes of response to hepatectomy (Fig. 5): delayed, suppressed and enhanced. The obtaining calculations correspond to the biological regeneration process [14].

\section{Conclusion}

The results of the performed numerical experiments showed that individually regeneration processes are not able to cope with the toxic factors that are accumulated in the body. The process of the body's functional state restoring requires the non-trivial strategy of liver regeneration. Numerical calculations revealed that the mathematical model corresponds to biological processes for different strategies of liver regeneration. Based on the calculations in the case of partial hapatectomy it is concluded that the mixed strategy of regeneration should be used for regeneration process.

Currently we are assume to expand and clarify this model. In particular, to expand the nomenclature of the main cells types and their states, taking into account zoning; add the processes of ductal reaction, development of fibrosis and cirrhosis; clarify the processes leading to damage the liver cells and etc. This model is the basis for the verification of the principles and criteria for optimal regulation of liver regeneration processes.

Acknowledgement. This research was partially supported by Akhiezer Foundation.
V. V. Karieva
ORCID ID
S. V. Lvov (iD https://orcid.org/0000-0003-4055-7172
L. P. Artyukhova (iD https://orcid.org/0000-0001-9724-9360

\section{REFERENCES}

1. B. Christ, U. Dahmen, K-H. Herrmann, M. Konig, JR. Reichenbach, T. Ricken, J. Schleicher, L. Ole Schwen, S. Vlaic, N. Waschinsky. Computational Modeling in Liver Surgery, Frontiers in Physiology. - 2017. - Vol. 8. Article 906. - P. 1-26. DOI: 10.3389 /fphys.2017.00906

2. Ye. Dayong, Zh. Minjie, V. Athanasios. A survey of self-organization mechanisms in multiagent systems, IEEE Transactions on Systems, Man, and Cybernetics. -2017. - Vol. 47. No. 3. - P. 441-462.

DOI: $10.1109 /$ TSMC.2015.2504350

3. M. Hwang, M. Garbey, S. A. Bercali, R. Tran-Son-Tay. Rule-Based Simulation of Multi-Cellular Biological Systems-A Review of Modeling Techniques, Cellular and Molecular Bioengineering. - 2009. - Vol. 2(3). - P. 285-294.

DOI: $10.1007 / \mathrm{s} 12195-009-0078-2$ 
4. V. V. Karieva, S. V. Lvov. Mathematical model of liver regeneration processes: homogeneous approximation, Visnyk of V.N.Karazin Kharkiv National University. Ser. "Mathematics, Applied Mathematics and Mechanics". - 2018. Vol. 87. - P. 29-41. DOI: 10.26565/2221-5646-2018-87-03

5. D. Palmes, H. U. Spiegel. Animal models of liver regeneration, Biomaterials. 2004. - Vol. 25(9). - P. 1601-1611. DOI: 10.1016/s0142-9612(03)00508-8

6. M. T. Pritchard, U. Apte. Models to study liver regeneration In Apte U (Ed.), Liver regeneration: Basic mechanisms, relevant models and clinical applications, Cambridge, MA: Academic press. - 2015. - P. 15-40.

7. G. M. Higgins, R. M. Anderson. Experimental pathology of the liver. Restoration of the liver of the white rat following partial surgical removal, Archives of Pathology. - 1931. - Vol. 12. - P. 186-202.

8. V. Papp, K. Dezso, V. Laszlo, P. Nagy, S. Paku. Architectural changes during regenerative and ontogenic liver growth in the rat, Liver Transplant. - 2009. Vol. 15. - P. 177-183 DOI: 10.1002/1t.21665

9. S. A. Mao, J. M. Glorioso, S. L. Nyberg. Liver regeneration, Translational Research. - 2014. - Vol. 163(4). - P. 352-362. DOI: 10.1016/j.trsl.2014.01.005

10. G. K. Michalopoulos. Principles of Liver Regeneration and Growth Homeostasis, Comprehensive Physiology.- 2013. - Vol. 3. - P. 485-513.

DOI: $10.1002 /$ cphy.c120014

11. G. K. Michalopoulos. Liver regeneration, Journal of Cellular Physiology. 2007. - Vol. 213(2). - P. 286-300. DOI: 10.1002/jcp. 21172

12. G. Michalopoulos, Marie C. DeFrances. Liver regeneration, Science.- 1997.Vol. 276. - P. 60-66. DOI: 10.1126/science.276.5309.60

13. A. Abu Rmilah, W. Zhou, E. Nelson, L. Lin, B. Amiot, S. L. Nyberg. Understanding the marvels behind liver regeneration, Wiley Interdiscip Rev Dev Biol. - 2019. - Vol.8(3):e340. DOI: 10.1002/wdev.340

14. D. Cook, B. A. Ogunnaike, R. Vadigepalli. Systems analysis of nonparenchymal cell modulation of liver repair across multiple regeneration modes, BMC Syst Biol. - 2015. - Vol. 9(71). - P. 1-24.

DOI: $10.1186 / \mathrm{s} 12918-015-0220-9$

Карєва В. В., Львов С. В., Артюхова Л. П. Різні стратегії в процесах регенерації печінки. Чисельні експерименти на математичній моделі. У статті розглядається узагальнена математична модель, яка описує процеси підтримки/відновлення (регенерації) динамічного гомеостазу печінки й явно залежить від керуючих параметрів. Запропонована математична модель процесів регенерації печінки $є$ узагальненням таких відомих моделей популяційної динаміки, як узагальнені рівняння 
Лотки-Вольтерра, рівняння Лотки-Вольтерра з запізнілими аргументами, інтегродиференціальні рівняння Вольтерра. Під час розробки цієї моделі було зроблено наступні припущення: однорідне наближення, незалежність біологічних процесів, помірний токсичний вплив. У заданій математичній моделі процес регенерації печінки здійснюється за рахунок процесів реплікації, гіперплазії, поліплодії, ділення двоядерних клітин і контрольованого апоптозу. Всі ці процеси необхідні для адекватного моделювання регенерації печінки. На прикладі одиничного і постійного токсичного впливу показано, що окремо вищевказані процеси не в змозі впоратися 3 токсичними факторами, які накопичуються в організмі. Процес відновлення функціонального стану організму вимагає завдання нетривіальної стратегії регенерації печінки, яка буде враховувати усі можливі шляхи підтримки/відновлення динамічного гомеостазу печінки. Чисельні розрахунки виявили, що задана математична модель при різних стратегіях регенерації печінки відповідає біологічним процесам. На основі виконаних обчислень у випадку часткової гапатектомії зроблено висновок, що при регенерації печінки повинна використовуватися змішана стратегія регенерації. Надалі передбачається поширити математичну модель, щоб вона враховувала процеси підтримки/відновлення динамічного гомеостазу печінки, які відбуваються під впливом сильних токсинів, тобто за допомогою стволових клітин і фіброзу. А також планується обгрунтувати принципи і критерії оптимальності регуляції процесів підтримки/відновлення динамічного гомеостазу печінки.

Ключові слова: математична модель; регенерація печінки; чисельний експеримент.

V. V. Karieva, S. V. Lvov, L. P. Artyukhova. Different strategies in the liver regeneration processes. Numerical experiments on the mathematical model. It is considered the generalized mathematical model which describes the processes of maintaining / restoring dynamic homeostasis (regeneration) of the liver and obviously depends on the control parameters. The model is a system of discrete controlled equations of the Lotka - Volterra type with transitions. These equations describe the controlled competitive dynamics of liver cell populations' (hepatic lobules) various types in their various states and controlled competitive transitions between types and states. To develop this model there were accepted such assumptions: homogeneous approximation; independence of biological processes; small toxic factors. In the mathematical model the process of the liver regeneration occurs due to hyperplasia processes, replication, polyplodia and division of binuclear hepatocytes into mononuclear and controlled apoptosis. All these processes are necessary for adequate modeling of the liver regeneration. For example, single and constant toxic functions show that the above processes are not able to cope with the toxic factors that are accumulated in the body. The process of restoring the body's functional state requires the non-trivial strategy of the liver regeneration. Numerical calculations revealed that the mathematical model corresponds to biological processes for different strategies of the liver regeneration. Based on the calculations in the case of partial hapatectomy it is concluded that the mixed strategy of regeneration should be used for the regeneration process. Henceforward it is planned to extend the mathematical model in the case of the liver regeneration, which occurs under the influence of strong toxins, that is, using the stem cells and fibrosis. It is also supposed to justify the principles and criteria for optimal regulation of the processes of maintaining / restoring liver's dynamic homeostasis.

Keywords: mathematical model; liver regeneration; numerical experiment.

Article history: Received: 25 February 2020; Final form: 10 June 2020; Accepted: 15 June 2020. 